\title{
ANTERIOR SURGICAL MANAGEMENT OF THE CERVICOTHORACIC JUNCTION LESIONS AT TI AND T2 VERTEBRAL BODIES
}

\author{
Asdrubal Falavigna', Orlando Righesso ${ }^{2}$, Darcy Ribeiro Pinto-Filho ${ }^{3}$, Alisson Roberto Teles ${ }^{4}$
}

\begin{abstract}
Lesions of the cervicothoracic junction have a high propensity for causing instability and present unique challenges in the surgical treatment. Several surgical approaches to this region have been described in the literature. We report our experience in the surgical treatment of six patients with unstable lesions involving the cervicothoracic junction at $\mathrm{T} 1$ and $\mathrm{T} 2$ vertebral bodies. The patients underwent an anterior left Smith-Robinson approach and manubriotomy. Mesh and cervical plate system were used for stabilization and reconstruction of the region. No complication related to the surgical procedure was observed. In our experience, in injuries involving the $\mathrm{T} 1$ and $\mathrm{T} 2$ vertebral bodies, the transmanubrial approach offers good working room to remove the lesions and anterior reconstruction.
\end{abstract}

KEY WORDS: spine, cervicothoracic junction, instability, surgical treatment.

\begin{abstract}
Manejo cirúrgico via anterior das lesões da junção cérvico-torácica nos corpos vertebrais de T1 e T2
Resumo - Lesões da junção cérvico-torácica têm alta tendência em causar instabilidade e apresentam grandes desafios ao tratamento cirúrgico. Diversas abordagens cirúrgicas a esta região foram descritas na literatura. Relatamos nossa experiência no tratamento cirúrgico de seis pacientes com lesões instáveis envolvendo a junção cérvico-torácica em corpos vertebrais de T1 e T2. Os pacientes foram submetidos a uma abordagem anterior de Smith-Robinson pela esquerda e manubriotomia. Mesh e placa cervical foram utilizados para estabilização e reconstrução da região. Nenhuma complicação relacionada ao procedimento cirúrgico foi observada. Em nossa experiência, em lesões que envolvem os corpos vertebrais de $\mathrm{T} 1$ e $\mathrm{T} 2$, a abordagem transmanubrial oferece bom campo de trabalho para remoção das lesões e estabilização anterior.
\end{abstract}

PALAVRAS-CHAVE: coluna, junção cervico-torácica, instabilidade, tratamento cirúrgico.

The cervicothoracic junction is defined as the area extending from vertebral segments $\mathrm{C} 7$ to $\mathrm{T} 4$, and includes the lower brachial plexus, the thoracic outlet and the parenchymatous, vascular and nervous structures of the upper mediastinum. This region is a transition area from a mobile, lordotic cervical spine to a rigid, kyphotic thoracic spine'. It is susceptible to injury because of the weight transfer from the anterior column to the posterior col$\mathrm{umn}^{2}$ and the vertebral index decreases from $\mathrm{C} 6$ to $\mathrm{T} 7$ vertebrae, causing added stress to be applied to the more narrow and thinner vertebrae ${ }^{3}$. Several studies demonstrate that surgical procedures in the cervicothoracic junction can destabilize this region, mainly laminectomies at $\mathrm{C} 7-\mathrm{T}^{4,5}$ and spinal fusions ending at this junction ${ }^{5,6}$.

Pathological processes such as tumors, trauma, degen- eration and infection, which usually occur in the anterior segment of the vertebrae, frequently determine instability of this segment ${ }^{7}$. Progressive instability of this area ultimately leads to kyphosis and spinal cord compression, neurological involvement being a common complication as high as $80 \% \%^{7,8}$. This predisposition may be due to the small spinal canal and the tenuous blood supply ${ }^{7,8}$. The surgical treatment goals of cervicothoracic pathologies are neural decompression, immediate stabilization, restoration of anatomical spinal alignment and early rehabilitation. Different surgical approaches to the cervicothoracic junction have been described ${ }^{1,4,7-29}$. As most pathologies affect the anterior column often an anterior approach is required to treat this lesions. Access to the anterior aspect of the cervicothoracic junction is difficult

'Department of Neurosurgery, Universidade de Caxias do Sul, Hospital Saúde, Caxias do Sul RS, Brazil; ${ }^{2}$ Department of Orthopedics, Hospital Saúde, Caxias do Sul RS, Brazil; ${ }^{3}$ Department of Thoracic Surgery, Universidade de Caxias do Sul, Hospital Geral, Caxias do Sul RS, Brazil; ${ }^{4}$ Medical student, Universidade de Caxias do Sul, Caxias do Sul RS, Brazil

Received 5 December 2007. Accepted 23 February 2008.

Dr. Asdrubal Falavigna - Rua General Arcy da Rocha Nóbrega 401/602 - 95040-290 Caxias do Sul RS - Brasil. E-mail: asdrubal@doctor.com 
and potentially dangerous because of bony obstructions such as the manubrium, clavicle and ribs and because of nearby vital structures such as great blood vessels, esophagus, trachea, recurrent laryngeal nerve, thoracic duct and sympathetic ganglions.

We report our experience with the anterior approach to the cervicothoracic junction at $\mathrm{T} 1$ and $\mathrm{T} 2$ vertebral bodies and its results.

\section{METHOD}

We reviewed the records of six patients with unstable lesion of the cervicothoracic junction at $\mathrm{T} 1$ and $\mathrm{T} 2$ vertebral bodies surgically treated by anterior surgical approach. All patients had metastatic or traumatic vertebral body lesions diagnosed by computed tomography and magnetic resonance image. Clinical data of patients are summarized in Table.

All patients underwent an anterior approach to the cervicothoracic junction by a left Smith-Robinson approach and manubriotmy. The patient was placed in the supine position on the operating table under general endotracheal anaesthesia. The neck was extended slightly using a folded sheet. Both wrists have traction bands applied to pull the arms down for lateral radiographic imaging during the procedure. Left vertical incision was performed along the medial aspect of the sternocleidomastoid extending along the midline of the sternum down two centimeters from the Louis angle to permit manubriotomy. Subplatys- mal flaps were elevated and retained by sutures. The sternomastoid, sternohyoid and sternothyroid muscles were sectioned, allowing connection of the region of the lower cervical and the upper thoracic spine. The sternum was split partially (manubriotomy) and the level of dissection was confirmed by fluoroscopy. The lesion was removed using a microscope and the reconstruction was done using mesh and a cervical plate system. A suction drain was used in the substernal space. The manubriotomy was closed with steel wires number three. The patients kept 48 hours in the intensive care unit and then discharged to a hospital room.

\section{RESULTS}

The mean age was 58.4 years (range, 30-72 years) and three patients were male. All patients had $\mathrm{T} 1$ involvement and two of them had T2 involvement. Most patients had metastatic disease and presented with severe local pain. Two patients had signs of spinal cord compression at the time of diagnosis, one had suffered a traumatic spinal cord injury. The mean surgical time was 3.7 hours (range, 2.8-5.2 hours) and the mean bleeding was $310 \mathrm{~mL}$ (range, $180-520 \mathrm{~mL}$ ). No complication related to the surgical procedure was observed. One patient had a lung infection few days after the surgery. All the patients had significant relief from pain and good neurological recovery. Case 4

Table. Summary of patients.

\begin{tabular}{|c|c|c|c|c|c|c|c|c|c|}
\hline Case & $\begin{array}{l}\text { Age/ } \\
\text { Sex }\end{array}$ & Level & $\begin{array}{l}\text { Clinical } \\
\text { manifestations }\end{array}$ & Pathology & $\begin{array}{l}\text { Recon- } \\
\text { struction }\end{array}$ & $\begin{array}{l}\text { Surgical } \\
\text { time }\end{array}$ & Bleeding & $\begin{array}{l}\text { Hospital } \\
\text { stay (days) }\end{array}$ & Outcome \\
\hline 1 & $65 / F$ & $\mathrm{~T} 1$ & $\begin{array}{l}\text { Severe local pain } \\
\text { Left Cervicobrachialgia } \\
\text { Strength grade III at left } \mathrm{C} 7 \text { and } \mathrm{T} 7\end{array}$ & $\begin{array}{l}\text { Lung } \\
\text { metastasis }\end{array}$ & $\begin{array}{l}\text { mesh and } \\
\text { plate }\end{array}$ & $\begin{array}{c}2.8 \\
\text { hours }\end{array}$ & $200 \mathrm{~mL}$ & 7 & $\begin{array}{l}\text { No complications, marked neu- } \\
\text { rological improvement with pain } \\
\text { relief and strength improvement } \\
\text { (grade V), died } 18 \text { months later } \\
\text { of progressive systemic disease. }\end{array}$ \\
\hline 2 & $53 / \mathrm{F}$ & $\mathrm{T} 1$ & $\begin{array}{l}\text { Severe local pain } \\
\text { Bilateral cervicobrachialgia }\end{array}$ & $\begin{array}{l}\text { Thyroid } \\
\text { metastasis }\end{array}$ & $\begin{array}{l}\text { mesh and } \\
\text { plate }\end{array}$ & $\begin{array}{c}3.2 \\
\text { hours }\end{array}$ & $350 \mathrm{~mL}$ & 8 & $\begin{array}{l}\text { No complications, pain relief, } 9 \\
\text { months of follow-up. }\end{array}$ \\
\hline 3 & $68 / \mathrm{M}$ & $\mathrm{T} 1-\mathrm{T} 2$ & $\begin{array}{l}\text { Severe local pain } \\
\text { Crural paraparesis grade III }\end{array}$ & $\begin{array}{l}\text { Lung } \\
\text { metastasis }\end{array}$ & $\begin{array}{l}\text { mesh and } \\
\text { plate }\end{array}$ & $\begin{array}{c}4.2 \\
\text { hours }\end{array}$ & $400 \mathrm{~mL}$ & 6 & $\begin{array}{l}\text { No complications, marked neu- } \\
\text { rological improvement with pain } \\
\text { relief and strength improvement } \\
\text { (grade V), died } 6 \text { months after } \\
\text { surgery of the progressive sys- } \\
\text { temic disease. }\end{array}$ \\
\hline 4 & $30 / \mathrm{M}$ & $\mathrm{T} 1$ & Crural paraparesis grade II & $\begin{array}{l}\text { Fracture } \\
\text { and luxation } \\
\text { at } \mathrm{C} 7-\mathrm{Tl}\end{array}$ & $\begin{array}{l}\text { mesh and } \\
\text { posterior } \\
\text { fixation }\end{array}$ & $\begin{array}{c}5.2 \\
\text { hours }\end{array}$ & $520 \mathrm{~mL}$ & 7 & $\begin{array}{l}\text { No complications, strength } \\
\text { grade IV with } 24 \text { months of fol- } \\
\text { low-up. }\end{array}$ \\
\hline 5 & $62 / \mathrm{F}$ & $\mathrm{T} 1-\mathrm{T} 2$ & $\begin{array}{l}\text { Severe local pain } \\
\text { Bilateral cervicobrachialgia }\end{array}$ & $\begin{array}{l}\text { Melanoma } \\
\text { metastasis }\end{array}$ & $\begin{array}{l}\text { mesh and } \\
\text { plate }\end{array}$ & $\begin{array}{c}3.7 \\
\text { hours }\end{array}$ & $180 \mathrm{~mL}$ & 6 & $\begin{array}{l}\text { No complications, pain relief, } \\
\text { died } 6 \text { months after surgery of } \\
\text { the progressive systemic disease. }\end{array}$ \\
\hline 6 & $72 / \mathrm{M}$ & $\mathrm{T1}$ & $\begin{array}{l}\text { Severe local pain } \\
\text { Bilateral cervicobrachialgia } \\
\text { Strength grade III at } \mathrm{Tl}\end{array}$ & $\begin{array}{l}\text { Lung } \\
\text { metastasis }\end{array}$ & $\begin{array}{l}\text { mesh and } \\
\text { plate }\end{array}$ & $\begin{array}{c}3.3 \\
\text { hours }\end{array}$ & $220 \mathrm{~mL}$ & 9 & $\begin{array}{l}\text { Lung infection in the immediate } \\
\text { pos-op, pain relief and strength } \\
\text { improvement, follow-up of } 13 \\
\text { months. }\end{array}$ \\
\hline
\end{tabular}




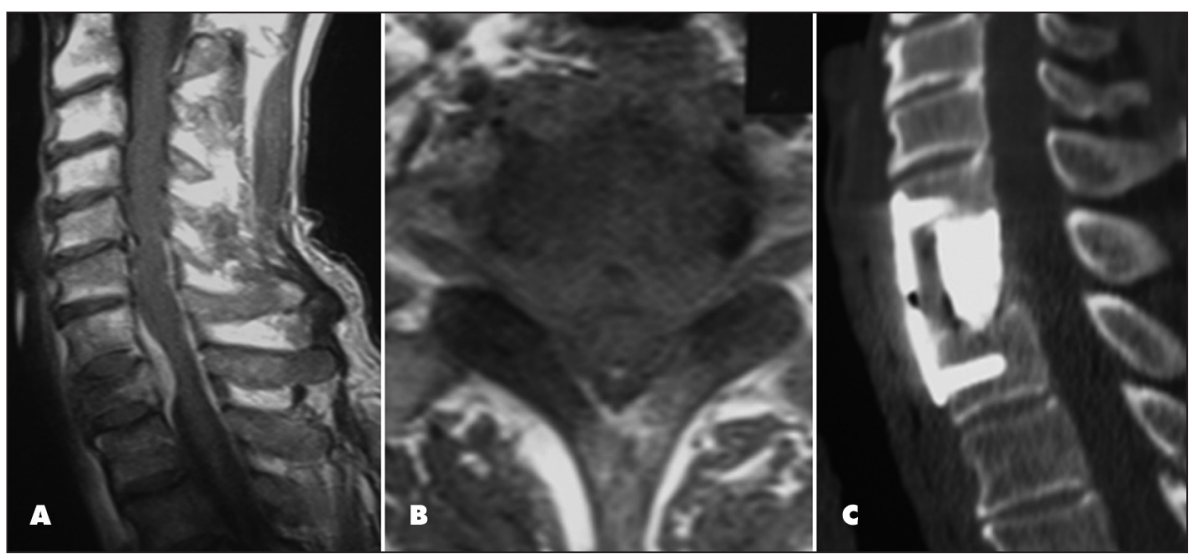

Figure. Preoperative sagittal (A) and axial (B) T2-weighted magnetic resonance show a thyroid metastasis involving $T 1$ and ventral spinal cord compression at this level. Postoperative computed tomography scan (C) shows anterior mesh and plate instrumentation between C7 and T2 after transmanubrial approach.

was submitted to posterior fixation of the spine because of posterior ligament and bone instability. The patients stayed in hospital for 7 days in average (range, 6-9 days). Figure illustrates the case 2.

\section{DISCUSSION}

Lesions of the cervicothoracic junction have a high propensity for causing instability and present unique challenges in surgical treatment. The pathologies involving this region often produce spinal cord compression, which was noted in three of seven cases presented in this series. Several surgical approaches to the cervicothoracic junction have been described in the literature. Posterior approaches are disadvantageous because of a destabilization effect, inadequate visualization of the vertebral body pathology, and the need for a long posterior construct to restore stability with a higher complication rate than anterior or lateral approaches $\mathrm{s}^{7,15,28,30}$.

The limitations of a posterior exposure have resulted in the development of various posterolateral and anterior approaches ${ }^{7-26,29}$. The first description of a posterolateral approach to the cervicothoracic area was the costotransversectomy described in 1894 by Ménard ${ }^{22}$. Capener ${ }^{10}$ described the lateral thoracotomy approach, which provided a more extensive posterolateral exposure afforded by a resection of a longer rib segment. A modification of Capener's technique was described by Larson into the lateral extracavitary approach ${ }^{18}$, which improved exposure and reduced morbidity. Fessler and colleagues ${ }^{13}$ proposed the parascapular extrapleural lateral approach, which improved exposure of all the upper thoracic vertebrae. The disadvantages of this procedure are prolonged surgery (10-12 hours), excessive blood loss and inefficiency for the pathologies extending into the $\mathrm{C} 7$ vertebrae ${ }^{15}$. Fur- thermore, pulmonary-related complications are common following this approach ${ }^{31}$.

Many authors suggest a simple anterior supramanubrial cervicotomy to be used to reach the anterior portion of the proximal dorsal vertebrae ${ }^{26,32,33}$. Although this approach is not very invasive, it does not permit good visualization and anterior reconstruction below $\mathrm{Tl}$, which results from the patient's anatomical characteristics, such as marked junctional kyphosis, congenital high sternum, short neck or large shoulders ${ }^{7,15,24}$. Cauchoix and Binet ${ }^{11}$ proposed an anterior approach combining the supraclavicular approach with a median sternotomy. This sternal splitting approach enables the exposure of the whole cervicothoracic junction up to $\mathrm{T} 4^{16,24}$. Hodgson et al..$^{14}$ reported a surgical mortality rate of $40 \%$ with the sternal splitting approach and recommended the anterolateral thoracotomy approach to the cervicothoracic junction, which had only $4 \%$ mortality. However, the anterolateral thoracotomy approach provides limited access to the lower cervical spine because of obstruction by the scapula and upper ribs. Louis ${ }^{20}$ improved the sternal splitting approach combining this procedure with the anterior Smith-Robinson approach ${ }^{27}$, permitting access from $\mathrm{C} 2$ to $\mathrm{T}^{16}$. In our experience, performing a partial sternotomy (manubriotomy) we are able to reach until T4, but are unable to achieve additional caudal exposure despite using a complete sternotomy because of the limited retraction of the aortic $\operatorname{arc}^{15}$ and this procedure can minimize the risks of sub-sternal dissection ${ }^{21}$. Upper lateral transthoracic or extrapleural approach is mandatory for total removal and reconstruction of the lesions of T4 and below ${ }^{15}$. Despite the high mortality reported by Hodgson et al. ${ }^{14}$ following an anterior surgical procedure of the cervicothoracic junction, many authors ${ }^{8,12,15,16,21,23,24,26,29,32,33}$ believe that the 
direct anterior approach to the region is safe and effective, as demonstrated in our cases.

Some authors reported the need for clavicle resection for both more extended lateral exposure and bone fusion ${ }^{9,7,19,29}$. This technique was described by Sunderasan et al. ${ }^{29}$ in a series of seven patients with tumors involving the cervicothoracic junction until T2. They proposed removing of a rectangular block of sternum instead of complete splitting and adding a resection of the medial third of the clavicle for better exposure and to use it as a strut graft. For tumors with significant intrathoracic extension, a trapdoor technique has been described to achieve gross-total resection ${ }^{25}$. Although this approach improves anterior visualization and reduces the risk of spinal cord manipulation, it carries the potential risks associated with thoracotomy. In our experience, using microscopic visualization and the new systems for spinal reconstruction we can achieve good results in terms of tumor removal and stabilization using cervical exposure and manubriotomy.

The anterior approach to the cervicothoracic junction require accurate knowledge of the numerous anatomical structures that hinder this region. The right brachiocephalic vein passes vertically, joining the left brachiocephalic or innominate vein and coursing obliquely in front of the aortic arch behind the manubrium to form the superior vena cava at the level of the right second rib. The aortic arch limits this surgical approach to the area along T4-T5. It is oriented behind the lower aspect of the manubrium and left brachiocephalic vein. The brachiocephalic arterial trunk passes behind the manubrium. The recurrent laryngeal nerve arises from the vagus and courses around the subclavian artery on the right and around the aortic arch on the left. It crosses the operative field obliquely at a higher level on the right side; contrary on the left side, it reaches the tracheoesophageal groove more caudally having a vertical trajectory less liable to injury with left-sided exposure ${ }^{24}$. Besides, the right nerve may not be recurrent from the vagus in one percent of the patients and rise at a higher level in the neck $\mathrm{k}^{34}$. A left approach is desirable to decrease the risk of recurrent laryngeal nerve injury, knowing that, on this side, the thoracic duct is presented ascending on the left side of the thoracic inlet and the esophagus, behind the left subclavian, flowing into the internal jugular vein.

Steinmetz et al. ${ }^{5}$ studied the factors associated with treatment failure in cervicothoracic junction surgery. In their large series of 593 patients, they observed treatment failure in 14 patients. Uninstrumented laminectomy and ventral multilevel corpectomies (two or three levels) across the cervicothoracic junction were associated with fusion failure in $38 \%$ and $16.7 \%$, respectively. A trend toward treatment failure was noted in cases in which dorsal constructs ended at the C7 vertebrae, although this was not statistically significant. The authors recommended supplemental dorsal instrumentation in cases of multilevel corpectomies, posterior instability or dorsal cervicothoracic laminectomies with extension of the dorsal hardware to $\mathrm{T1}$ or T2. Besides, treatment failure was also associated with histories of prior cervical surgery, deformity correction and tobacco use. In case 4, we performed an anterior decompression followed by a posterior stabilization because of posterior ligament and bone instability.

In our experience, a left Smith-Robinson approach combined with manubriotomy offers good exposure and working room for the cervicothoracic lesions involving $\mathrm{T} 1$ and $\mathrm{T} 2$ vertebral bodies. This approach requires accurate knowledge of surgical anatomy, as many vital structures are present in this area. We used mesh and a cervical plate system with good results for stabilize and reconstruct this region.

\section{REFERENCES}

1. An HS, Wise JJ, Xu R. Anatomy of the cervicothoracic junction: a study of cadaveric dissection, cryomicrotomy, and magnetic resonance imaging. J Spinal Disord 1999;12:519-525.

2. Pal GP, Routal RV. A study of weight transmission through the cervical and upper thoracic regions of the vertebral column in man. J Anat 1986;148:245-261.

3. Boyle JJ, Singer KP, Milne N. Morphological survey of the cervicothoracic junctional region. Spine 1996;21:544-548.

4. An HS, Vaccaro A, Cotler JM, Lin S. Spinal disorders at the cervicothoracic junction. Spine 1994;19:2557-2564.

5. Steinmetz MP, Miller J, Warbel A, Krishnaney AA, Bingaman W, Benzel EC. Regional instability following cervicothoracic junction surgery. J Neurosurg Spine 2006;4:278-284.

6. Drennan JC, King EW. Cervical dislocation following fusion of the upper thoracic spine for scoliosis. A case report. J Bone Joint Surg Am 1978;60:1003-1005.

7. Le H, Balabhadra R, Park J, Kim D. Surgical treatment of tumors involving the cervicothoracic junction. Neurosurg Focus 2003;15:E3.

8. Sapkas G, Papadakis S, Katonis P, Roidis N, Kontakis G. Operative treatment of unstable injuries of the cervicothoracic junction. Eur Spine J 1999;8:279-283.

9. Birch R, Bonney G, Marshall RW. A surgical approach to the cervicothoracic spine. J Bone Joint Surg Br 1990;72:904-907.

10. Capener N. The evolution of lateral rhachotomy. J Bone Joint Surg Br 1954;36-B:173-179.

11. Cauchoix J, Binet JP. Anterior surgical approaches to the spine. Ann R Coll Surg Engl 1957;21:234-243.

12. Charles R, Govender S. Anterior approach to the upper thoracic vertebrae. J Bone Joint Surg Br 1989;71:81-84.

13. Fessler RG, Dietze DD Jr., Millan MM, Peace D. Lateral parascapular extrapleural approach to the upper thoracic spine. J Neurosurg 1991;75:349-355.

14. Hodgson AR, Stock FE, Fang HS, Ong GB. Anterior spinal fusion: the operative approach and pathological findings in 412 patients with Pott's disease of the spine. Br J Surg 1960;48:172-178.

15. Kaya RA, Turkmenoglu ON, Koc ON, et al. A perspective for the selection of surgical approaches in patients with upper thoracic and cervicothoracic junction instabilities. Surg Neurol 2006;65:454-463.

16. Knoller SM, Brethner L. Surgical treatment of the spine at the cervicothoracic junction: an illustrated review of a modified sternotomy approach with the description of tricks and pitfalls. Arch Orthop Trauma Surg 2002;122:365-368.

17. Kurz LT, Pursel SE, Herkowitz HN. Modified anterior approach to the cervicothoracic junction. Spine 1991;16(Suppl 10):S542-S547.

18. Larson SJ, Holst RA, Hemmy DC, Sances A, Jr. Lateral extracavitary approach to traumatic lesions of the thoracic and lumbar spine. J Neurosurg 1976;45:628-637. 
19. Lesoin F, Thomas CE 3rd, Autricque A, Villette L, Jomin M. A transsternal biclavicular approach to the upper anterior thoracic spine. Surg Neurol 1986;26:253-256.

20. Louis R. Die Chirurgie der Wirbelsäule. Chirurgische Anatomie und operative Zugangswege. Berlin: Springer-Verlag, 1985.

21. Luk KD, Cheung KM, Leong JC. Anterior approach to the cervicothoracic junction by unilateral or bilateral manubriotomy: a report of five cases. J Bone Joint Surg Am 2002;84-A:1013-1017.

22. Ménard V. Causes de la paraplégie dans le mal de Pott. Son traitement chirurgical par l'ouverture directe du foyer tuberculeux des vertebres. Rev Orthop 1894;5:47-64.

23. Micheli LJ, Hood RW. Anterior exposure of the cervicothoracic spine using a combined cervical and thoracic approach. J Bone Joint Surg Am 1983;65:992-997.

24. Miscusi M, Bellitti A, Polli FM. Surgical approaches to the cervico-thoracic junction. J Neurosurg Sci 2005;49:49-57.

25. Nazzaro JM, Arbit E, Burt M. "Trap door" exposure of the cervicothoracic junction: technical note. J Neurosurg 1994;80:338-341.

26. Resnick DK. Anterior cervicothoracic junction corpectomy and plate fixation without sternotomy. Neurosurg Focus 2002;12:E7.
27. Robinson RA, Smith GW. Anterolateral disc removal and interbody fusion for cervical disc syndrome. Johns Hopkins Hosp Bull 1953;96:223-224.

28. Sundaresan N, DiGiacinto GV, Krol G, Hughes JE. Spondylectomy for malignant tumors of the spine. J Clin Oncol 1989;7:1485-1491.

29. Sundaresan N, Shah J, Foley KM, Rosen G. An anterior surgical approach to the upper thoracic vertebrae. J Neurosurg 1984;61:686-690.

30. Siegal T, Siegal T. Surgical decompression of anterior and posterior malignant epidural tumors compressing the spinal cord: a prospective study. Neurosurgery 1985;17:424-432.

31. Resnick DK, Benzel EC. Lateral extracavitary approach for thoracic and thoracolumbar spine trauma: operative complications. Neurosurgery 1998;43:796-802.

32. Gieger M, Roth PA, Wu JK. The anterior cervical approach to the cervicothoracic junction. Neurosurgery 1995;37:704-709.

33. Comey $\mathrm{CH}$, McLaughlin MR, Moossy J. Anterior thoracic corpectomy without sternotomy: a strategy for malignant disease of the upper thoracic spine. Acta Neurochir (Wien) 1997;139:712-718.

34. Sanders G, Uyeda RY, Karlan MS. Nonrecurrent inferior laryngeal nerves and their association with a recurrent branch. Am J Surg 1983; 146:501-503. 